\title{
Effect of Thermal Treatment on the Quality of Honey Samples from Crete
}

\author{
Slim Blidi ${ }^{1}$, Panagiota Gotsiou ${ }^{1}$, Sofia Loupassaki ${ }^{1,}$, Spyros Grigorakis ${ }^{1}$ and Antony C. Calokerinos ${ }^{2,}$ \\ ${ }^{1}$ Department of Food Quality \& Chemistry of Natural Products, Mediterranean Agronomic Institute of Chania \\ (M.A.I.Ch.)/Centre International de Hautes Etudes Agronomiques Méditerranéennes, P.O. Box 85, Chania 73100, \\ Greece. \\ ${ }^{2}$ Department of Chemistry, School of Physical Science, National and Kapodistrian University of Athens, \\ Panepistimiopolis, Athens 15771, Greece. \\ Email: calokerinos@chem.uoa.gr, sofia@maich.gr
}

\begin{abstract}
The aim of the current study was to investigate the effect of the main thermal treatments used in practice by beekeepers and packagers on hydroxymethylfurfural content and diastase activity of Cretan honey. Results showed a significant alteration of both quality parameters under heating at $65{ }^{\circ} \mathrm{C}$ for $6 \mathrm{~h}(P<0.05)$ while heating at $45{ }^{\circ} \mathrm{C}$ for $24 \mathrm{~h}$ was found to be the least severe treatment with regards to the variation of the two quality parameters $(P<0.05)$. After heating, a significant differentiation was also observed in the variation of both HMF content and diastase activity according to the botanical origin of the honey sample $(P<0.05)$. Pine honey was the most resistant sample in hydroxymethylfurfural formation in all heating procedures and multifloral honey was the least altered in its enzymatic activity through the whole thermal process.
\end{abstract}

Keywords: Honey, thermal treatment, botanical origin, HMF, diastase activity.

\section{Introduction}

Honey is composed of a complex mixture of water, carbohydrates and numerous other minor compounds. In fact, it includes more than 400 different substances including organic acids, proteins, enzymes, aroma substances, mineral substances, pigments and waxes [1]. Considering the interest generated by all the properties associated with honey, several processing operations have been introduced to ensure a safe, pleasant and homogeneous presentation of the final product [1]. These processing steps generally require exposure to heat in order to reduce viscosity and to prevent crystallization or fermentation of the honey [1].

Gonnet et al [1] were the first to suggest heating at $78{ }^{\circ} \mathrm{C}$ for $6-7$ min as the best pasteurizing condition to avoid damage to the quality of honey. Since then, a wide range of heating temperatures ranging from 30 to $140{ }^{\circ} \mathrm{C}$ for a few seconds up to several hours have been practiced by honey producers worldwide, with the aim to reduce the water content in honey below $20 \%$ for shelf life prolongation $[1,2$, 3]. Subramanian [1] suggested that conventional honey processing includes preheating (to about $40{ }^{\circ} \mathrm{C}$ ), straining, clarification by means of filtration and heating of the product at $60-65{ }^{\circ} \mathrm{C}$ for $25-30 \mathrm{~min}$. In industrial plants, heating is done in special large surface heat exchange systems used with a heat source only a few degrees above the temperature to which the honey is to be heated [1]. However, an uncontrolled thermal processing of honey may also result in product quality deterioration and even in caramelization due to significant losses that occur in color, texture, flavor, enzymatic activity and nutritive value. In fact, its low thermal conductivity makes uniform heating throughout a large body of honey very difficult and the use of high temperature heat sources like open flames or boiling water baths may quickly lead to significant alterations of the desirable characteristics of honey.

Hydroxymethylfurfural (HMF) content and diastase activity are quality parameters that are heatsensitive as they are increasing or decreasing respectively according to the intensity of the heating process $[1,8]$. For instance, Bogdanov [1] points out that thermal treatment, which may destroy the diastase activity, should be as long as 31 days at $40{ }^{\circ} \mathrm{C}$, but it can be shortened to $1.2 \mathrm{~h}$ at $80{ }^{\circ} \mathrm{C}$. Thus, these two criteria are extensively recognized as reliable parameters for assessment of freshness and/or 
overheating of honey. The International Regulatory Standards for Honey Quality from the European Honey Directive (2001/110/EC) and from the Codex Alimentarius Standard for Honey (2001) set a general lower limit equal to 8 (3 for citrus honey) for diastase activity, expressed as diastase number (DN), and a general limit of $40 \mathrm{mg} / \mathrm{kg}(15 \mathrm{mg} / \mathrm{kg}$ for citrus honey) for HMF content.

The effect of thermal treatment is known to vary among honeys of different botanical origin [10, 8]. For instance, Fallico [1] stated that, at low heating temperatures $\left(50{ }^{\circ} \mathrm{C}\right)$, eucalyptus, orange, Italian sainfoin and chestnut honey samples from Italy developed distinct amounts of HMF. In fact, chestnut honey did not form any HMF even after $144 \mathrm{~h}$ of heating. This difference of the trend was attributed to the time of heating, to free and total acidity as well as $\mathrm{pH}$ values. In a study on 4 Turkish honey samples, it was suggested also that the resistance to heat differs with respect to the botanical origin after finding that the most change-resistant honey in both diastase activity and HMF content was pine honey (Pinus nigra) honeydew honey as well as multifloral honey, followed by citrus honey (Citrus spp) and cotton honey (Gossypium herbaceum) [1]. Moreover, Turhan [6] could discriminate between the behavior of Turkish floral and honeydew honeys concluding that HMF content in floral honeys was more dependent on temperature changes when comparing to that of honeydew honey.

The aim of this study was to assess the effect of some of the thermal procedures widely used during honey processing in Crete on hydroxymethylfurfural (HMF) content and diastase activity of Cretan honeys that are coming from several botanical origins and that have not yet been investigated. In addition to that, a discrimination of the variation of the two quality parameters according to the botanical origin of the honey was attempted.

\section{$2 \quad$ Materials and Methods}

\section{$2.1 \quad$ Samples}

Fresh honey samples from different botanical origins of the island of Crete were provided by local beekeepers. In total, nine samples were studied: one sample was a pine honeydew honey (Pinus brutia), two samples constituted blends of nectar (either from thyme -Thymbra capitata- or heather - Erica verticillata) and pine honeydew, while six other samples came only from flower nectar: three of them are 'unifloral' (from one plant species: Citrus, thyme and eucalyptus); the other three were 'multifloral' nectar honeys (from different plant species: multifloral honey 1 was found to have a significant contribution from chestnut tree (Castanea sativa), multifloral honey 2 had significant contribution from myrtle nectar (Myrtus communis) and multifloral honey 3 had nectar contribution from various species (such as thyme, myrtle, heather, clover). Their botanical origin and authenticity were identified by the staff of the Laboratory of the Food Quality and Chemistry of Natural Products Department of MAICh, by performing analyses for physico-chemical properties [1] and honey microscopic examination [1, 2]. All parameters of the 9 honey samples were in accordance with the limits set by the European Directive for Honey (2001/110) and the relative Greek legislation. Honey samples were stored at $-18{ }^{\circ} \mathrm{C}$ until analysis.

\subsection{Thermal Treatment}

The experiment was conducted under isothermal treatment. Thermal treatment choices were based on common heating practices by beekeepers and manufacturers from Crete during honey processing. From each honey sample, three equal volumes of honey were weighed and transferred into 50-mL beakers. Beakers were then set into the water bath for the thermal treatment at $45{ }^{\circ} \mathrm{C}$ for 24 and $48 \mathrm{~h}$ and at $65{ }^{\circ} \mathrm{C}$ for 3 and $6 \mathrm{~h}$. When the time of isothermal treatment had elapsed, the honey was allowed to cool at $25^{\circ} \mathrm{C}$. The honey samples were then analyzed to determine diastase activity and HMF content.

\subsection{Moisture Content, Electrical Conductivity, pH and Free Acidity}

Moisture content was determined by measuring the refractive index at $20{ }^{\circ} \mathrm{C}$ according to the Harmonized Methods for Honey developed by the International Honey Commission [14]. The determination was conducted using an AR 200 digital hand-held refractometer (Leica, Germany). 
Electrical conductivity was measured at $20{ }^{\circ} \mathrm{C}$ in $20 \%$ (w/w) aqueous solutions of honey, according to the IHC method for honey [14] by using a hand-held meter Cond i330 conductivity meter (WTW Germany) equipped with a conductivity probe. The sample solution was prepared using doubledeionized water (Milli-Q Millipore 18.2 MXcm resistivity).

The $\mathrm{pH}$ values were obtained by titration to $\mathrm{pH} 8.3$ using a $\mathrm{pH}$-plus meter (LaMotte, USA) according to the IHC method for honey [14].

\subsection{Determination of Diastase Activity}

The Schade method was used for the determination of diastase activity according to the Harmonized Method for Honey developed by the International Honey Commission [14]. A standard solution of starch, capable of developing, with iodine, a blue color, is acted upon by the enzyme in the sample under standard conditions. The diminution in the blue color was measured at intervals using a UV-visible diode array 8452 A spectrophotometer (Hewlett-Packard, USA). A plot of absorbance against time was used to determine the time required to reach the specified absorbance at $660 \mathrm{~nm}$. The diastase activity was calculated as diastase number (DN), as follows:

$$
D N=\frac{300}{t_{x}}
$$

where $t_{x}$ is the reaction time in minutes.

Results were expressed as diastase number (DN). DN on the Schade scale, which corresponds to the Gothe scale number, is defined as the grams of starch hydrolyzed in $1 \mathrm{~h}$ at $40{ }^{\circ} \mathrm{C}$ per $100 \mathrm{~g}$ honey.

\subsection{Determination of Hydroxymethylfurfural}

The White method was used to determine HMF in the honey samples according to the Harmonized Methods of the European Commission of Honey [14]. The method is based on the determination of UV absorbance of HMF at $284 \mathrm{~nm}$ using a UV-visible diode array 8452 A spectrophotometer (HewlettPackard, USA). In order to avoid interference from other components at this wavelength, the difference between the absorbances of a clear aqueous honey solution and the same solution after addition of sodium bisulfite is determined. The HMF content is calculated after subtraction of the background absorbance at $336 \mathrm{~nm}$. HMF content expressed as $\mathrm{mg} / \mathrm{kg}$ was calculated by using the formula:

$$
H M F=\left(A_{284}-A_{336}\right) \times 149.7 \times 5 \times \frac{D}{W}
$$

where $\mathrm{A}_{284}=$ absorbance at $284 \mathrm{~nm}, \mathrm{~A}_{336}=$ absorbance at $336 \mathrm{~nm}, 149.7=$ constant, $\mathrm{D}=$ dilution factor, in case dilution is necessary, and $\mathrm{W}=$ weight in $\mathrm{g}$ of the honey sample.

\subsection{Statistical Analysis}

One way analysis of variance (ANOVA) was performed to discriminate between the trends of change regarding HMF content and diastase activity according to the botanical origin of the honey samples after the application of thermal treatments and to assess the effect of the different thermal procedures applied. The $F$-test was used to estimate the statistically significant differences $(P$-value $<0.05)$.

\section{Results and Discussion}

\subsection{Hydroxymethylfurfural Content}

A natural variation was observed in the HMF content among the fresh honey samples. In fact, the initial HMF concentration was found to be the lowest in the heather-pine blend $(1.40 \mathrm{mg} / \mathrm{kg})$ while it was the highest in the multifloral honey with chestnut pollen domination $(6.91 \mathrm{mg} / \mathrm{kg})$. None of the studied samples exceeded the limit of $40 \mathrm{mg} / \mathrm{kg}$ (Table 1). 
Table 1. Characteristics of the fresh honey samples studied (all values are from 3 repetitions and reported as average \pm standard deviation except for electrical conductivity).

\begin{tabular}{c|c|c|c|c|c|c}
\hline Sample & $\begin{array}{c}\text { Diastase } \\
\text { activity } \\
\text { (Schade } \\
\text { number) }\end{array}$ & $\begin{array}{c}\text { HMF } \\
(\mathbf{m g} / \mathbf{k g})\end{array}$ & $\mathbf{p H}$ & $\begin{array}{c}\text { Free } \\
\text { acidity } \\
(\mathbf{m e q} / \mathbf{k g})\end{array}$ & $\begin{array}{c}\text { Moisture } \\
\text { content } \\
(\mathbf{g} / \mathbf{1 0 0 g})\end{array}$ & $\begin{array}{c}\text { Electrical } \\
\text { conductivity } \\
(\mathbf{m S} / \mathbf{c m})\end{array}$ \\
\hline Citrus & $9.40 \pm 0.10$ & $3.24 \pm 0.05$ & $3.15 \pm 0.01$ & $28.50 \pm 0.50$ & $16.0 \pm 0.03$ & 0.28 \\
\hline Thyme & $18.27 \pm 0.06$ & $5.75 \pm 0.09$ & $3.26 \pm 0.02$ & $27.67 \pm 0.29$ & $15.8 \pm 0.02$ & 0.37 \\
\hline Eucalyptus & $15.03 \pm 0.31$ & $5.94 \pm 0.06$ & $3.55 \pm 0.02$ & $24.72 \pm 0.86$ & $15.4 \pm 0.02$ & 0.34 \\
\hline Pine & $18.37 \pm 0.25$ & $6.56 \pm 0.11$ & $4.78 \pm 0.03$ & $17.00 \pm 0.50$ & $14.2 \pm 0.02$ & 1.40 \\
\hline Multifloral 1 & $14.93 \pm 0.25$ & $6.91 \pm 0.11$ & $3.56 \pm 0.03$ & $24.00 \pm 0.50$ & $15.7 \pm 0.03$ & 0.27 \\
\hline Multifloral 2 & $25.57 \pm 0.31$ & $4.35 \pm 0.15$ & $3.56 \pm 0.02$ & $23.33 \pm 0.76$ & $16.0 \pm 0.02$ & 0.56 \\
\hline Thyme-Pine & $13.40 \pm 0.10$ & $6.64 \pm 0.06$ & $3.72 \pm 0.02$ & $22.17 \pm 0.29$ & $15.9 \pm 0.01$ & 0.34 \\
\hline Heather- & $11.47 \pm 0.21$ & $6.30 \pm 0.34$ & $4.04 \pm 0.02$ & $20.33 \pm 0.29$ & $13.8 \pm 0.02$ & 0.85 \\
\hline Pine & $11.30 \pm 0.26$ & $1.40 \pm 0.04$ & $4.21 \pm 0.03$ & $18.83 \pm 0.76$ & $13.6 \pm 0.01$ & 0.93 \\
\hline
\end{tabular}

A significant difference among heating temperatures on HMF content was observed $(P<0.05)$. This result showed that there was an increase in HMF at different thermal procedures. HMF content increased with increasing temperature and duration to reach a maximum for heating at $65{ }^{\circ} \mathrm{C}$ for $6 \mathrm{~h}$. Minimum effects were recorded after heating at $45{ }^{\circ} \mathrm{C}$ for $24 \mathrm{~h}$ and at $65{ }^{\circ} \mathrm{C}$ for $3 \mathrm{~h}$ while the intermediate effect was observed after heating at $45^{\circ} \mathrm{C}$ for $48 \mathrm{~h}$ (Tables 1 and 2, Figures 1 and 2).

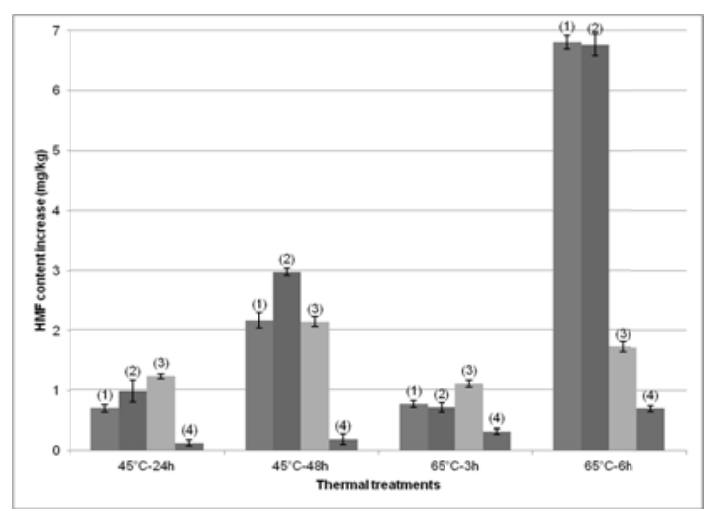

Figure 1. Variation of HMF content according to the different thermal treatments for (1) citrus, (2) thyme, (3) eucalyptus and (4) pine honeys.

Differences in HMF concentration changes among honey samples were examined at the botanical origin level and were found to be statistically significant $(P<0.05)$. In fact, pine honey was found to be the least affected in all applied thermal procedures with an average HMF increase ranging between 0.12 and $0.70 \mathrm{mg} / \mathrm{kg}$. Furthermore, both thyme-pine and heather-pine blends showed high resistance to the increase of HMF during the whole heating operation, having increases in the ranges of $0.14-1.21 \mathrm{mg} / \mathrm{kg}$ and $0.37-1.27 \mathrm{mg} / \mathrm{kg}$, respectively. On the other hand, citrus and thyme honeys exhibited the highest HMF rise when heating was prolonged up to $48 \mathrm{~h}$ at $45^{\circ} \mathrm{C}$ and to $6 \mathrm{~h}$ at $65^{\circ} \mathrm{C}$ with average increment values of 2.16 and $2.97 \mathrm{mg} / \mathrm{kg}\left(45^{\circ} \mathrm{C}-48 \mathrm{~h}\right)$ and 6.81 and $6.76 \mathrm{mg} / \mathrm{kg}\left(65{ }^{\circ} \mathrm{C}-6 \mathrm{~h}\right)$, respectively. Multifloral honeys were the most sensitive samples as regards HMF content increase at the early heating stages where multifloral honey 2 showed the most notable $\mathrm{HMF}$ formation after heating at $45^{\circ} \mathrm{C}$ for 24 $\mathrm{h}(1.48 \mathrm{mg} / \mathrm{kg})$ and multifloral honeys 1 and 3 having displayed the maximal HMF increase among the studied samples after heating for $3 \mathrm{~h}$ at $65{ }^{\circ} \mathrm{C}(1.59$ and $1.56 \mathrm{mg} / \mathrm{kg}$ of average increase, respectively) (Table 2, Figures 1 and 2). 


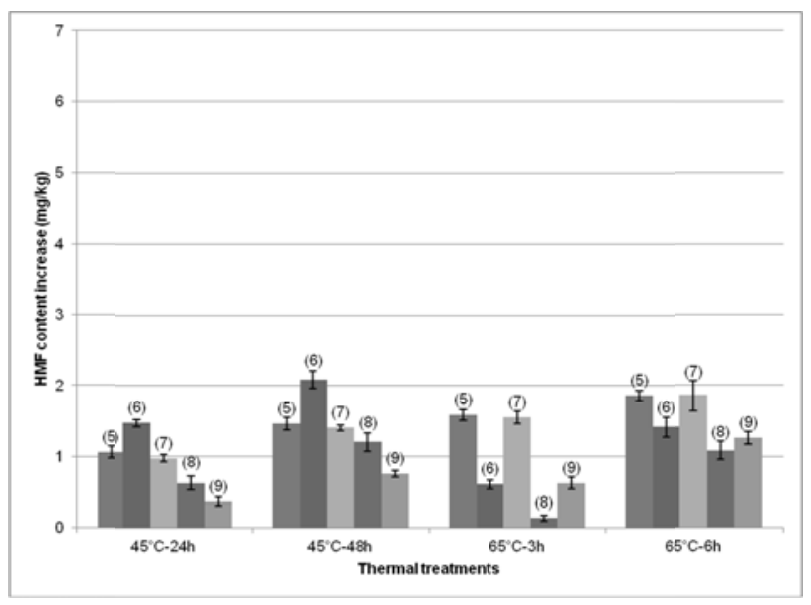

Figure 2. Variation of HMF content according to the different thermal treatments for (5) multifloral 1 (6) multifloral 2, (7) multifloral 3, (8) thyme pine blend and (9) heather pine blend honeys.

Table 2. Changes of HMF content after different thermal treatments (average values from 3 repetitions \pm standard deviation)

\begin{tabular}{|c|c|c|c|c|c|c|c|c|c|}
\hline \multirow[t]{2}{*}{ Sample } & \multicolumn{5}{|c|}{ HMF content $(\mathrm{mg} / \mathrm{kg})$} & \multicolumn{4}{|c|}{ HMF increase $(\mathrm{mg} / \mathrm{kg})$} \\
\hline & lue & $45^{\circ} \mathrm{C}-24 \mathrm{~h}$ & $45^{\circ} \mathrm{C}-48 \mathrm{~h}$ & $65^{\circ} \mathrm{C}-3 \mathrm{~h}$ & $65^{\circ} \mathrm{C}-6 \mathrm{~h}$ & $45^{\circ} \mathrm{C}-24 \mathrm{~h}$ & $45^{\circ} \mathrm{C}-48 \mathrm{~h}$ & $65^{\circ} \mathrm{C}-3 \mathrm{~h}$ & $65^{\circ} \mathrm{C}-6 \mathrm{~h}$ \\
\hline Citrus & & $3.94 \pm 0.04$ & $5.41 \pm 0.16$ & $4.01 \pm 0.09$ & $10.05 \pm 0.03$ & $0.69^{c} \pm 0.06$ & $2.16^{\mathrm{e}} \pm 0.13$ & $0.76^{\mathrm{b}} \pm 0.06$ & $6.81^{\mathrm{e}} \pm 0.11$ \\
\hline $\mathrm{Th}$ & 9 & .22 & \pm 0.03 & 0.10 & 12.5 & $0.97^{\mathrm{d}} \pm 0.18$ & $2.97^{\mathrm{f}} \pm$ & $0.70^{\mathrm{b}} \pm 0.08$ & $6.76^{\mathrm{e}} \pm 0.18$ \\
\hline Eucalypt & 06 & $7.15 \pm 0.08$ & $8.08 \pm 0.05$ & \pm 0.0 & 7.6 & \pm 0.04 & $2.14^{\mathrm{e}} \pm 0.04$ & 0.06 & $1.72^{\mathrm{d}} \pm 0.09$ \\
\hline Pine & $6.56 \pm 0.11$ & $6.68 \pm 0.10$ & $6.75 \pm 0.09$ & $6.87 \pm 0.06$ & $7.26 \pm 0.07$ & $0.12^{\mathrm{a}} \pm 0.03$ & $0.19^{\mathrm{a}} \pm 0.09$ & $0.31^{\mathrm{a}} \pm 0.05$ & $0.70^{\mathrm{a}} \pm 0.05$ \\
\hline Multifloral 1 & $6.91 \pm 0.11$ & $7.98 \pm 0.13$ & $8.38 \pm 0.20$ & $8.50 \pm 0.07$ & $8.77 \pm 0.04$ & $1.07^{\mathrm{de}} \pm 0.08$ & $1.47^{\mathrm{d}} \pm 0.09$ & $1.59^{\mathrm{d}} \pm 0.08$ & $1.86^{\mathrm{d}} \pm 0.07$ \\
\hline Multifloral 2 & $4.35 \pm 0.15$ & $5.83 \pm 0.21$ & $6.44 \pm 0.13$ & $4.96 \pm 0.13$ & $5.77 \pm 0.29$ & $1.48^{\mathrm{f}} \pm 0.05$ & $2.09^{\mathrm{e}} \pm 0.12$ & $0.61^{\mathrm{b}} \pm 0.06$ & $1.42^{\mathrm{c}} \pm 0.14$ \\
\hline Multifloral 3 & $6.64 \pm 0.06$ & $7.62 \pm 0.09$ & $8.05 \pm 0.03$ & $8.20 \pm 0.08$ & $8.50 \pm 0.20$ & $0.98^{\mathrm{de}} \pm 0.05$ & $1.41^{\mathrm{cd}} \pm 0.04$ & $1.56^{\mathrm{d}} \pm 0.09$ & $1.86^{\mathrm{d}} \pm 0.21$ \\
\hline Thyme-Pine & $6.30 \pm 0.34$ & $6.93 \pm 0.25$ & $7.52 \pm 0.22$ & $6.45 \pm 0.31$ & $7.40 \pm 0.22$ & $0.63^{\mathrm{c}} \pm 0.10$ & $1.21^{\mathrm{c}} \pm 0.13$ & $0.14^{\mathrm{a}} \pm 0.04$ & $1.09^{b} \pm 0.13$ \\
\hline Heather-Pine & $1.40 \pm 0.04$ & $1.77 \pm 0.04$ & $2.16 \pm 0.04$ & $2.03 \pm 0.06$ & $2.68 \pm 0.01$ & $0.37^{\mathrm{b}} \pm 0.06$ & $0.76^{\mathrm{b}} \pm 0.03$ & $0.63^{\mathrm{b}} \pm 0.08$ & $1.27^{\mathrm{bc}} \pm 0.09$ \\
\hline
\end{tabular}

Values with different superscript letters in a column are significantly different $(P<0.05)$

The results obtained are in agreement with results by other workers $[1,13]$ where pine honey was the most resistant in HMF increase followed by citrus and thyme honeys after heating at 45 and $65{ }^{\circ} \mathrm{C}$ for $24 \mathrm{~h}$.

The results of the present study obtained for Greek Eucalyptus honey from Crete differ from the ones by Fallico et al [12] in which Italian Eucalyptus honey did not develop any HMF after heating at $50{ }^{\circ} \mathrm{C}$ and $70{ }^{\circ} \mathrm{C}$ up to $48 \mathrm{~h}$. These differences could be due to the difference in the geographical origin and in the vegetation found in the various regions.

The variable sensitivity of honeys towards heating regarding HMF content can be attributed to the initial $\mathrm{pH}$ value $[6,12,13,17]$ and the initial free acidity $(\mathrm{pH})$ of honey. In fact, pine honey which was the most change-resistant in all thermal procedures, displayed the highest value of $\mathrm{pH}(4.78)$ and the lowest value of free acidity $(17.00 \mathrm{meq} / \mathrm{kg})$ among all studied samples. Citrus and thyme honeys, which were the most altered samples with the prolongation of heat had the lowest $\mathrm{pH}$ values $(3.15$ and 3.26 , respectively) and the highest free acidity values $(28.50$ and $27.67 \mathrm{meq} / \mathrm{kg})$.

\subsection{Diastase Activity}

A notable disparity was found in the initial diastase activity among the fresh honey samples. For instance, the multifloral honey 2 had the highest enzymatic activity (25.57 DN) while the citrus sample showed the lowest value $(9.40 \mathrm{DN})$. These discrepancies are said to be related to the floral origin of 
honey as well as the nectar flow and foraging patterns of the bees [1]. All the homey samples complied with the EU limits set for diastase activity.

Table 3. Changes of diastase activity after different thermal treatments (average values from 3 repetitions \pm standard deviation)

\begin{tabular}{|c|c|c|c|c|c|c|c|c|c|}
\hline \multirow[t]{2}{*}{ Sample } & \multicolumn{5}{|c|}{ Diastase activity (Schade number) } & \multicolumn{4}{|c|}{ Decrease of diastase activity (Schade number) } \\
\hline & Initial value & $45^{\circ} \mathrm{C}-24 \mathrm{~h}$ & $45^{\circ} \mathrm{C}-48 \mathrm{~h}$ & $65^{\circ} \mathrm{C}-3 \mathrm{~h}$ & $65^{\circ} \mathrm{C}-6 \mathrm{~h}$ & $45^{\circ} \mathrm{C}-24 \mathrm{~h}$ & $45^{\circ} \mathrm{C}-48 \mathrm{~h}$ & $65^{\circ} \mathrm{C}-3 \mathrm{~h}$ & $65^{\circ} \mathrm{C}-6 \mathrm{~h}$ \\
\hline Citrus & $9.40 \pm 0.10$ & $9.13 \pm 0.15$ & $8.33 \pm 0.35$ & $7.53 \pm 0.06$ & $5.07 \pm 0.06$ & $0.27^{\mathrm{a}} \pm 0.06$ & $1.07^{\mathrm{ab}} \pm 0.25$ & $1.87^{\mathrm{c}} \pm 0.06$ & $4.33^{\mathrm{fg}} \pm 0.06$ \\
\hline Thyme & $18.27 \pm 0.06$ & $16.87 \pm 0.06$ & $14.84 \pm 0.23$ & $15.30 \pm 0.10$ & $13.50 \pm 0.26$ & $1.20^{\mathrm{d}} \pm 0.10$ & $3.43^{\mathrm{f}} \pm 0.21$ & $2.97^{\mathrm{d}} \pm 0.06$ & $4.77^{\mathrm{g}} \pm 0.31$ \\
\hline Eucalyptus & $15.13 \pm 0.12$ & $14.37 \pm 0.15$ & $13.23 \pm 0.21$ & $13.10 \pm 0.10$ & $12.73 \pm 0.15$ & $0.77^{\mathrm{b}} \pm 0.06$ & $1.90^{\mathrm{d}} \pm 0.10$ & $2.03^{\mathrm{c}} \pm 0.21$ & $2.40^{\mathrm{bc}} \pm 0.10$ \\
\hline Pine & $18.37 \pm 0.25$ & $17.70 \pm 0.26$ & $16.50 \pm 0.26$ & $17.07 \pm 0.15$ & $15.43 \pm 0.23$ & $0.67^{\mathrm{b}} \pm 0.06$ & $1.87^{\mathrm{d}} \pm 0.12$ & $1.30^{b} \pm 0.10$ & $2.93^{\mathrm{d}} \pm 0.15$ \\
\hline Multifloral 1 & $14.93 \pm 0.25$ & $13.67 \pm 0.12$ & $12.90 \pm 0.20$ & $13.17 \pm 0.12$ & $12.17 \pm 0.38$ & $1.07^{\mathrm{cd}} \pm 0.35$ & $2.03^{\mathrm{d}} \pm 0.06$ & $1.77^{\mathrm{c}} \pm 0.15$ & $2.77^{\mathrm{cd}} \pm 0.15$ \\
\hline Multifloral 2 & $25.57 \pm 0.31$ & $24.90 \pm 0.26$ & $22.97 \pm 0.35$ & $24.27 \pm 0.35$ & $22.10 \pm 0.44$ & $0.67^{\mathrm{b}} \pm 0.15$ & $2.60^{\mathrm{e}} \pm 0.10$ & $1.30^{\mathrm{b}} \pm 0.10$ & $3.47^{\mathrm{e}} \pm 0.25$ \\
\hline Multifloral 3 & $13.40 \pm 0.10$ & $13.13 \pm 0.12$ & $12.53 \pm 0.23$ & $12.70 \pm 0.10$ & $12.03 \pm 0.15$ & $0.27^{\mathrm{a}} \pm 0.06$ & $0.87^{\mathrm{a}} \pm 0.15$ & $0.70^{\mathrm{a}} \pm 0.00$ & $1.37^{\mathrm{a}} \pm 0.12$ \\
\hline Thyme-Pine & $13.47 \pm 0.21$ & $12.43 \pm 0.23$ & $11.93 \pm 0.15$ & $12.20 \pm 0.10$ & $11.33 \pm 0.12$ & $0.63^{\mathrm{b}} \pm 0.06$ & $1.53^{\mathrm{c}} \pm 0.06$ & $1.27^{\mathrm{b}} \pm 0.12$ & $2.13^{\mathrm{b}} \pm 0.15$ \\
\hline Heather-Pine & $11.30 \pm 0.26$ & $11.12 \pm 0.29$ & $10.50 \pm 0.26$ & $9.47 \pm 0.25$ & $7.07 \pm 0.12$ & $0.18^{\mathrm{a}} \pm 0.03$ & $0.80^{\mathrm{a}} \pm 0.10$ & $1.83^{\mathrm{c}} \pm 0.12$ & $4.23^{\mathrm{f}} \pm 0.15$ \\
\hline
\end{tabular}

Values with different superscript letters in a column are significantly different $(P<0.05)$

A significant difference among heating temperatures on diastase activity was observed $(P<0.05)$. The enzymatic activity decreased within the different thermal procedures attaining a maximum decrease after heating at $65{ }^{\circ} \mathrm{C}$ for $6 \mathrm{~h}$ where the heather-pine blend went under the limit of 8 DN. All honeys were affected the least after heating at $45^{\circ} \mathrm{C}$ for $24 \mathrm{~h}$. Both of the intermediate thermal procedures gave an activity reduction to a similar extent (Tables 1 and 3, Figures 3 and 4 ).

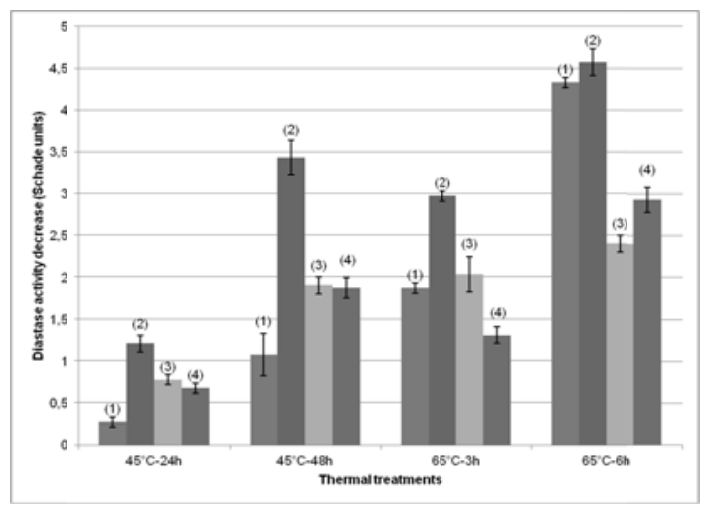

Figure 3. Variation of diastase activity according to the different thermal treatments for (1) citrus, (2) thyme, (3) eucalyptus and (4) pine honeys.

The variation of diastase level is distinct for all honey origins. Therefore, the interaction between honey origins and heating temperature levels on diastase level $(P<0.05)$ was significant. Thyme honey was the most vulnerable in the 4 applied thermal treatments with average enzymatic activity losses ranging between 1.20 and $4.77 \mathrm{DN}$ while multifloral honey 3 was subjected to the most limited alteration with mean diastase number reductions ranging between 0.27 and $1.37 \mathbb{D N}$. After having low enzymatic activity decrease after heating at $45{ }^{\circ} \mathrm{C}$, citrus honey and the blend heather pine saw their diastase activities declining significantly after the prolongation of heat at $65{ }^{\circ} \mathrm{C}$ up to $6 \mathrm{~h}$, with decreases of 4.33 and $4.23 \mathrm{DN}$, respectively, leading even the blend to go under the limits set for diastase activity. The five other samples had moderate enzymatic activity decreases. 


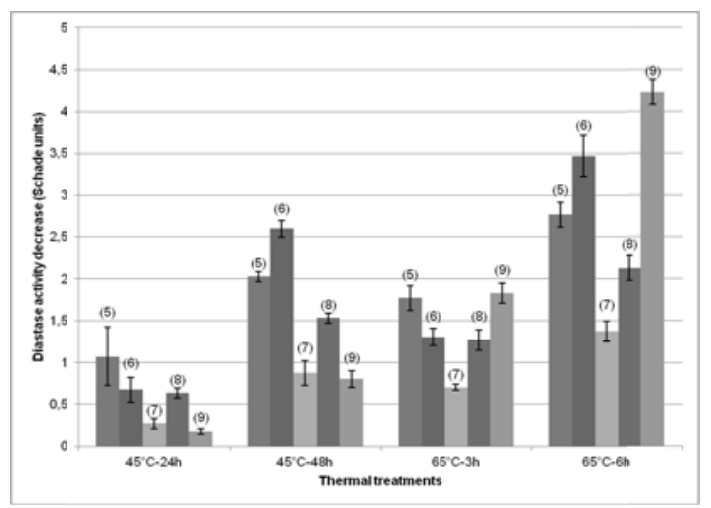

Figure 4. Variation of diastase activity according to the different thermal treatments for (5) multifloral 1 (6) multifloral 2, (7) multifloral 3, (8) thyme pine blend and (9) heather pine blend honeys.

The possible reason for these findings could reside in a hypothesis concerning diastase activity variation caused by heating that is based on structural changes in enzyme molecules [3]. Starting from the theory of Eyring, heating causes enzyme molecules to acquire sufficient kinetic energy to surmount the mutual repulsive forces between the electron clouds of their constituent atoms and they come very close to one another and form a transition state. Once the energy barrier is overcome, the irreversible denaturation reaction of an enzyme occurs, expressed in the modification of its protein structure. The number of enzyme molecules denatured is proportional to the number of enzyme molecules that have free energy to form the transition state and that implicitly depends on the intensity of heat treatment.

Accordingly, thyme, citrus and heather-pine honeys would have a high number of enzyme molecules gaining an energy state superior to the energetic barrier, which then would be under distortion. Consequently, a drastic decrease of enzymatic activity can then be observed after heating at $65{ }^{\circ} \mathrm{C}$ for 6 h. For multifloral honey 3, the number of activated molecules which could overcome the energetic barrier of the transition stage would be low. Therefore, the reaction towards irreversible denaturation would not occur to any large extent. At the end of the heating procedure, all activated molecules that did not have sufficient energy to surpass the energy barrier would return to a native-like state. Thus, the enzymatic activity of honey will not be highly disturbed and could be partially recovered. Comparable behavior was reported by Richardson and Hyslop [1] in the case of other food enzymes, such as alkaline phosphatase in milk and peroxidases and lipoxygenase in vegetables and fruits.

In the case of honey, this differentiation in the behavior can be attributed to the different age, diet, physiological stage of the bees and abundance of nectar flow [1], all factors that can influence the enzymatic activity and its variation.

\section{Conclusions}

HMF concentration increased and diastase activity decreased with the increasing intensity of heat in temperature and duration. Although HMF content and diastase activity did not pass the specified limits after all the applied thermal treatments (except for DN of the blend heather-pine honey after heating at $65{ }^{\circ} \mathrm{C}$ for $6 \mathrm{~h}$ ), it is recommended to avoid the most extreme heating procedures that are prolonged in time, since there are other quality and sensory criteria that should be taken into consideration such as color, flavor, invertase activity and nutritive value related to vitamins and minerals.

HMF content formation was also found to be related to the botanical origin of the honey. In the present case, pine honey and blends of thyme-pine and heather-pine honeys were found to be the most resistant and this might be related to the composition of the honey and specifically the initial $\mathrm{pH}$ and the initial free acidity values.

Diastase activity variation was also differentiated among the studied honey samples. However, it is more likely related to factors such as age, diet, physiological stage of the bees and abundance of nectar flow rather than the botanical origin of the honey itself.

Therefore, during processing, beekeepers and honey processors should accord special attention to the physicochemical parameters discussed here and heat honey only moderately $\left(45{ }^{\circ} \mathrm{C}\right.$ for $24 \mathrm{~h}$ ) which 
would be sufficient to reduce viscosity and prevent crystallization without altering other quality parameters.

\section{References}

1. H.D.Belitz, W. Grosch and P. Schieberle, "Food Chemistry". Berlin. Springer Verlag: GmbH \& Co, 2005.

2. B. Abu-Jdayil, A.A. Ghzawi, K.I.M. Al-Malah and S. Zaitoun S. 2002. "Heat effect on rheology of light- and dark-coloured honey", Journal of. Food Engineering, vol. 51, no. 1, pp. 33-38, 2002.

3. E. Tosi, P. Martinet, M. Ortega, H. Lucero and E. Ré, "Honey diastase activity modified by heating". Food Chemistry, vol. 106, no 4, pp. 883-887, 2008.

4. M. Gonnet, P. La Vie and P. Nogueira-Neto, "Etude de quelques caractéristiques des miels récoltés par certains Méliponines brésiliens".Comptes Rendus de l'Académie des Sciences Paris, vol. 258, pp. 3107-3109, 1964.

5. D. M. Wakhle, R. P. Phadke, D.V.E. Pais and K.S. Nair, "Design for honey processing Unit, Part II", Indian Bee Journal, vol. 58, no. 1, pp. 5-9, 1996.

6. I. Turhan, N. Tetik, M. Karhan, F. Gurel, H. Reyhan Tavukcuoglu, "Quality of honeys influenced by thermal treatment". LWT-Food Science and Technology, vol. 41, no. 8, pp. 1396-1399, 2008.

7. W. Guo, Y. Liu, X. Zhu and S. Wang, "Temperature-dependent dielectric properties of honey associated with dielectric heating", Journal of Food Engineering, vol. 102, no. 3, pp. 209-216, 2011.

8. R. Subramanian, H.U. Hebbar and N.K. Rastogi, "Processing of honey: A review", International Journal of Food Properties, vol. 10, no. 1, pp. 127-143, 2007.

9. R. Krell, "Value-added products from beekeeping", FAO Agricultural Services Bulletin No. 124, Food and Agriculture Organization of the United Nations, Rome 1996.

10.M.A. Ramirez Cervantes,S.A. Gonzalez Novelo and E. Sauri Duch, "Effect of the temporary thermic treatment of honey on variation of the quality of the same during storage", Apiacta vol. 35, no. 4, pp.162 - 170, 2000.

11.S. Bogdanov, "Liquefaction of honey", Apiacta, vol. 28, no. 1, pp. 4-10, 1993.

12.B. Fallico, M. Zappalà, E. Arena and A. Verzera, "Effects of conditioning on HMF content in unifloral honeys", Food Chemistry, vol. 85, no. 2, pp. 305-313, 2004.

13.N. Sahinler, "Effects of heating and storage on hydroxymethylfurfural and diastase activity of different Turkish honeys", Journal of Apicultural Research, vol. 46, no. 1, pp. 34-39, 2007.

14.S. Bogdanov, "Harmonized methods of the International Honey Commission. International Honey Commission", International Honey Commission, pp. 1-61, 2009.

15.J. Louveaux, A. Maurizio and G. Vorwohl, "Methods of Melissopalynology", Bee World, vol. 59, no. 4, pp. 139157, 1978.4. K. Czajkowski, S. Fitzgerald, I. Foster, and C. Kesselman, "Grid information services for distributed resource sharing," in High Performance Distributed Computing, 2001. Proceedings. 10th IEEE International Symposium on. IEEE, 2001, pp. 181-194.

16.W. Von der Ohe, L. Persano Oddo, M.L. Piania, M. Morlot and P. Martin, "Harmonized methods of melissopalynology", Apidologie, vol. 35, suppl. 1, pp. S18-S25, 2004.

17.S. Karabournioti and P. Zervalaki, "The effect of heating on honey HMF and invertase", Apiacta, vol. 36, no. 4, pp.177-181, 2001.

18.A. Amri and A. Ladjama, "Enzymes activities, hydroxymethylfurfural content and pollen spectrum of some Algerian honey", African Journal of Agricultural Research, vol. 10, no. 7, pp. 613-622, 2015.

19.T. Richardson and D. Hyslop, "Enzimas" In: O. Fennema (Ed.), Quimica de los Alimentos, Acribia, Spain, pp. 451-456, 1992.

20.L. Persano Oddo, M.G. Piazza and P. Pulcini, "Invertase activity in honeys", Apidologie, vol. 30, no. 1, pp. 5765, 1999. 